\title{
Managerial Pay and Executive Turnover in the Czech and Slovak Republics*
}

\author{
Tor Eriksson \\ Aarhus School of Business \\ Prismet, Silkeborgvej 2, Aarhus C \\ Denmark \\ E-mail: tor@asb.dk
}

\begin{abstract}
Despite the crucial role played by managers in changing the functioning of labour markets in transition economies, research on the determinants of executive pay and CEO turnover in these countries is almost non-existent. The current paper aims at adding to this minuscule literature. For this purpose I make use of a unique data set containing relevant firm-manager information from the Czech and Slovak Republics in the late nineties. This allows me to examine the influence of individual and in particular firm characteristics, such as, size, ownership type, industry and region, as well as corporate performance on chief executive compensation levels and changes therein and on the probability of the executive being turned over.
\end{abstract}

JEL Codes: M52, P31, J31, J44

Keywords: Managerial Compensation, CEO Turnover, Corporate Performance

- The research reported in this paper has been financed by the EU-PHARE/ACE programme (contract P98-1003-R). I am grateful to Pavel Mrázek for help with the data and to Jingkun Li and Mariola Pytlikova for excellent research assistance. 


\section{Introduction}

During the last ten years the Central and Eastern European economies have been going through transition and privatisation processes, which have established a new firm and ownership structure. As a consequence, many of the early top managers have had to leave their positions and at the same time new managerial positions have been created in the new-borne firms. Needless to say, due to the sheer magnitude and pace of the changes as well as the dearth of entrepreneurs and managers with market economy experience, the pathway from state socialism to capitalism has been far from frictionless.

Labour markets have a prominent role in the transition to a market economy because of the great need to reallocate labour, but also because that is where the social costs of the restructuring process arise. This holds also for the managerial labour market, as the management in both new and old, but restructured firms, plays a crucial role in changing the functioning of labour markets in a direction more conducive for productive activities. Their task is not made easier by the fact that during state socialism, incentives to pursue policies to improve firm productivity were largely absent. Management under communism was rather characterised by motivational problems, strong risk aversion and extensive managerial slack. As characterised by Djankov and Murrell (2002),

“... the typical manager was a production engineer and not a businessman. Managers faced a mix of monetary and career-based incentives, which were a function of plan fulfillment, enterprise performance, and political loyalty. Profits and efficiency were much less important than they are under capitalism" (p. 742).

A key feature of the new markets for executives is the high levels of compensation relative to other wage earners. Finding the adequate level of compensation and differences between different types of firms, industries and regions therein, is a huge challenge in countries that for one or two generations have practised egalitarian remuneration.

As is emphasized by e.g. Aghion, Blanchard and Burgess (1994) and by Shleifer and Vishny (1997), the incentive systems of managers are crucially important for transition reforms to be successful. Management should be rewarded for reforming firms in a more market-oriented direction. For this you need for example incentives rewarding managers for downsizing state- 
owned firms and for other productivity-improving measures. Two types of incentives are important here. One is significant stakes in the performance of the firms, either in the form of performance-related pay or ownership of stock. Another is career concerns. Managers of stateowned firms are likely to be more willing to restructure if privatisation is imminent and is going to create a market for managers (Roland and Sekkat 2000). Since in transition economies, executives have considerable power - indeed, they appear to have more power than their colleagues in advanced market economies (King 2001) - providing them with the right incentives is presumably even more important than elsewhere.

There is, however, very little systematic evidence about the functioning of managerial labour markets in these countries. Scholars have rather focused their attention on the effects of corporate governance issues and the influence of ownership of firms on the success of the transition processes; see Estrin (2002). In fact, to the best of my knowledge, there is only one study of the determinants of executive compensation in a CEE transition economy. ${ }^{1}$ Jones and Kato (1995) ${ }^{2}$ examine the relationship between executive pay firm performance in Bulgarian, state- and nonstate-owned firms, during the early post-Communist period, 1989-92. ${ }^{3}$ In addition, there are a few studies of managerial incentives in Chinese enterprises. Thus, for instance, Groves, Hong, McMillan and Naughton (1994, 1995) study how changes in managerial contracts affect Chinese firms' performance in terms of total factor productivity growth. Although interesting in themselves, these studies have however little bearing on the CIS and EE countries, as in China privatisation was not an option. The primary aim of this paper is to add to this minuscule literature.

There is considerably more research about pay and pay determinants for wage earners in general; see the survey by Svejnar (1999). However, like the scant evidence on managerial pay, this literature is predominantly concerned with changes in the functioning of labour markets during the first years of the transition process. One distinguishing feature of the current paper is its focus on the post-transition years, that is, a period when you would expect the countries to have made

\footnotetext{
${ }^{1}$ Characteristically, the recent special issue on transition economies in Journal of Economic Perspectives (2002, Winter) does not give one single reference to this line of research.

${ }^{2}$ In addition to the studies mentioned below, there is a paper by Eriksson, Gottvald and Mrazek (1999), in which we make use of the same data source, but for the year 1996/7 and for the Czech Republic only, and examine some determinants of managerial pay differentials.
} 
the central choices regarding wage formation and labour market institutions and therefore, also expect to be observing the main features of the emerging capitalist economy.

In addition to an analysis of the determinants of managerial pay, I also look at factors influencing the probability that a chief executive is turned over, as this is another potentially important element in managerial incentives. The role and importance of managerial turnover has been examined by Barberis, Boycko, Shleifer and Tsukanova (1996), Claessens and Djankov (1999) and Frydman, Hessel and Rapaczynski (1999).

Not all transition countries have chosen the same pathway to a market economy. Another contribution of the paper is the comparison of two countries (which once even formed a single country) that have followed quite different routes: the Czech Republic and Slovakia. ${ }^{4}$ The data for the empirical analysis are, however, collected in the same way - as a matter of fact, by the same consulting firm.

The remainder of the paper is organised as follows. Next the data to be used is briefly described. Section 3 contains the empirical analysis of the determinants of managerial compensation. The fourth section is concerned with turnover of chief executives. Finally, the fifth section concludes.

\section{Data description}

The data sets used in this paper have been constructed by combining information from several sources. The bulk of the data is a series of cross-sections (parts of which can be made longitudinal) containing information about managerial employees in 839 Czech and 912 Slovak firms during the years 1997 to 2000. The two main data sets have been collected by Trexima Zlin, a Czech private consulting company specialised in human resource management, and by its sister company in Slovakia, Trexima Bratislava. One of these companies' major activities is the development and maintenance of the Average Earnings Information System (AIES) in

\footnotetext{
${ }^{3}$ See also Jones, Kato and Avramov (1995). Moreover, in a follow-up study, Jones and Kato (1998) report results for the period 1992-95.

${ }^{4}$ Although these two countries differ in many respects, they do both belong to the more successful end of the spectrum of transition economies.
} 
cooperation with the Ministries of Labour and Social Affairs and the Statistical Offices in the Czech and Slovak Republics.

The AEIS provides detailed information about the labour costs in different occupations and at the regional and industry levels. This information is gathered from firms in terms of individual level data. Thus, AEIS contains information about wages in 400 occupations including the managerial ones. The information regarding the managers in SR in our data se is obtained exclusively from the AEIS, whereas in CR additional information is obtained from the Survey of Managerial Staff Earnings, which also carried out by Trexima Zlin.

For the Czech Republic data on firms is available from two sources. One is a firm register (Obchodni vestnik) and another is the Albertina database. Both sources contain information about the performance of firms and some basic accounts data, for part of the firms covered in the AIES. Unfortunately, I do not have access to corresponding information for Slovakia.

The individual level data do not contain individual level identification numbers, whereas Trexima uses an identification number of firms. Thus, merging different cross-section in order to create panel data at the level of individuals is not possible. Following firms over time is easier, albeit not always without problems. The same applies to specific groups of employees, such a managerial employees. For this paper a great effort has been devoted to the construction of short panels of firms, CEO's and managerial employees.

Descriptive statistics for the variables used in the subsequent empirical analyses are set out in Table 1. From this it can be seen that the mean compensation level is clearly higher in Czech Republic (the exchange rate is about 1.44), but there are no big differences on average regarding the composition of total compensation. As regards individual characteristics, there are no noteworthy differences, except for the fact that the proportion of female managers is higher in Slovakia. The average size of the firms studied is larger in Czech Republic. The proportion of state-owned firms is higher in Slovak Republic, but the fraction of private-owned firms is roughly the same. The difference is due to the much larger share of firms with a so-called mixed ownership structure in Czech Republic. Another difference is the considerably larger share of Slovak companies in the services sector, and correspondingly lower proportions in other sectors. 


\section{Managerial pay equation estimations}

\subsection{CEO compensation}

Since the late eighties a huge literature on CEO compensation has accumulated; see the survey by Murphy (1999). The bulk of this research is concerned with CEO pay in the United States and focuses on how responsive changes in executive compensation are to changes in corporate performance. Thus, the idea is to estimate the key parameter in the principal-agent model. ${ }^{5}$ Recent papers by Lazear $(2000,2002)$ have, however, emphasized the important insight that in addition to the incentive effects, compensation schemes relating pay to performance also have sorting effects, which moreover may be quite strong. In other words, firms that use performance pay schemes are not only inducing their employees to perform better, but are also more likely to attract better performing employees.

The aim of the analysis in the current paper is broader; in addition to the pay and performance relationship, I also examine the determinants of the variation in managers' compensation levels. Thus, my focus is on the roles of individual and firm characteristics in explaining differences in managerial compensation. For this purpose I estimate conventional Mincerian earnings equations augmented with a number of firm level variables. "Pay" refers to total compensation, made up of a base salary component, which as can be seen from Table 1 is about 66-70 per cent of total pay, an individually determined premium pay component, bonuses and compensation for board membership. Furthermore, I also consider a strong form of incentives: the probability of being removed out of office. Due to data limitations, this can only be done for chief executives.

To begin with, I look at the estimates for the individual characteristics; see Table 2. A first thing worth noting is that for SR there is clearly a concave age-earnings profile, whereas for CR chief executives there is no statistically significant relationship. For Slovak CEO's the relation is moreover shifting over time, and as a consequence of that, earnings reach their maximum (58.5 years) later in year 2000 than in 1997 (55.9). One interpretation of the difference in the age estimates is that labour market experience, a considerable part of which derives from the 
Communist period, still counts in SR, whilst in CR which has made stronger advances towards a market economy, this no longer is the case. Note, however, that the mean age of chief executives is one year lower in SR.

The gender differential, which is based on rather few observations on female executives ( 7 and 17 per cent in CR and SR, respectively), is relative large, hovering between 20 and 40 per cent. Not only are there fewer female top managers in CR, the gender differential is also somewhat bigger.

Having a university education is rewarded in terms of higher earnings for CEO's in both countries. The return is higher in CR, but at least for the last year of observation it is on the increase in the SR, too. The returns are large relative to what have been found for executives in other countries (Eriksson 2000).

Turning next to the firm characteristics, we may note that firm size has a positive effect on executive compensation. Moreover, the effect is fairly large; in particular in Slovakia where it is twice as large as in the Czech Republic. The firm size distributions differ between the two countries, and hence, in our samples, too. On average the firms are considerably bigger in CR (almost twice the number of employees as in the average SR firm), but the SR size distribution is more dispersed. Positive size effects on CEO pay are also frequently found in mature capitalist economies (Rosen 1992; Conyon and Murphy 2000) and are typically thought of as reflecting the fact that heading a bigger company requires more managerial skills, for which they are compensated accordingly. However, during the Communist system, managers of large firms with many employees, also had more political power, and hence, better possibilities to obtain higher pay. ${ }^{6}$ But even during the transition period strong connections between big firms and politics are relatively common. So, it cannot be ruled out that a strong size effect may be capturing some remaining rigidity in the managerial pay structure. At any rate, the estimates imply that there are strong incentives for the chief executives to increase the size of the firm - something which is not necessarily consistent with profitability -- and that there are few incentives to downsizing, even when this would increase efficiency and profitability.

\footnotetext{
5 A competing view of CEO compensation, that managers are simply setting their own pay and are extracting rents has received less attention in the economics literature; for an exception and a review, see Bertrand and Mullainathan (2001) and Bebchuk, Fried and Walker (2001), respectively.

6 Both Groves et al. (1995) and Jones and Kato (1996) find a positive pay-firm size link in their analyses of China and Bulgaria, respectively.
} 
As regards the impact of the ownership structure of the firms on CEO compensation, I find, with one exception, a similar pattern in both countries. Compared to purely private-owned firms (the reference category), heads of cooperatives and chief executives of state-owned firms earn less. The state-owned firms constitute a smaller share of the Czech firms (a little below a fifth) than in Slovak Republic, but in the latter the share is declining (from a third to a fourth) during the years studied. There are some indications that in both countries the CEO's in state-owned firms are loosing in pay relative to those in private-owned firms. ${ }^{7}$ This finding suggests that privatisation and marketisation has lead to a stronger discipline on firms in the state sector. The trend is especially noteworthy in view of the fact that the state-owned firms that have survived are in all likelihood superior performers compared to those that have not.

Foreign owned firms, which not only are relatively rare (10 per cent of the firms in the samples), but are presumably also a rather selected group of firms, compensate their chief executives with a pay that exceeds that of private firm managers by about 40 per cent. ${ }^{8}$ The remaining category, firms with a mixed ownership is very rare in SR, whilst it accounts for 13 per cent of the firms in the Czech sample. CEO's in the Czech firms with mixed ownership are paid 30 per cent more than in Slovakia. I have no detailed information regarding the nature of these mixed companies, but if, as seems likely, many of these are old and semi-privatised firms, whereas the purely private-owned firms are predominantly new firms, then the relatively large wage gain to executives in mixed firms is not necessarily good news.

The industry affiliation of firms has a similar impact on CEO pay in both countries. The compensation of executives in agriculture is considerably lower than that of executives in other industries. The only industry in which CEO compensation is significantly above average is

\footnotetext{
${ }^{7}$ Eriksson et al. (1999) used Czech data from the same sources as the current paper but from years 1995 and 1996 (and for several categories of managers) and found that state-owned firms paid their managers more than privateowned companies. Thus, executives in state-owned firms were able to extract some rent. As can be seen from Table 3 , the negatively signed coefficient to the state-owned firm dummy is increasing over time indicating that the rent extraction possibilities are gradually reduced.

${ }^{8}$ It should be noted that Trexima uses a rather stringent definition of foreign ownership, namely that more than 50 per cent of the firm's capital should be in foreign hands. This means, presumably that some firms with a smaller foreign capital share is included in the category "mixed ownership". I have no information about the nationality of the executives in foreign-owned firms.
} 
banking. ${ }^{9}$ In general the inter-industry CEO pay differentials in Czech and Slovak republics resemble those observed in capitalist economies. The industry of the firm is also found be of some importance in explaining differences in levels of compensation in countries like the United States, United Kingdom and Denmark (Conyon and Murphy 2000; Eriksson 2000). Due to lack of data, in the current analysis I cannot include some potentially interesting influences like risk and growth potential of firm. According to the standard principal-agent model executives in highrisk firms (industries) want to have higher expected pay levels and firms with good investment opportunities need better managers. ${ }^{10}$ To some extent both of these factors are industry-specific and may in part be picked up by the industry dummies included. Thus, they are not entirely neglected by the empirical model used here. But I cannot, of course, disentangle their effects.

Regional differences remain significant even after catering for individual and firm characteristics. There is a clear effect of the company being located in the capital area: executive pay is lower in most of the regions outside Prague or Bratislava. As the home region of the firm is defined as the region where it's headquarters are located, and as this in many cases the capital region, the regional differences estimates are most likely understated. In CR the regional differentials are fairly persistent, and in some cases as large as 30 per cent, while in SR executives in the regions outside the capital region up to 1999 earned 20 per cent less than managers in Bratislava. Then, suddenly in 2000, the differentials are halved and most of them turn insignificant. I have no explanation for this observation, however.

Finally, I have included lagged corporate performance variables as regressors. Unfortunately, these are only available for the Czech Republic. I have tried a number of different performance measures, all giving basically the same results as those shown in Table 2 for the (gross) profits over sales ratio: a positive coefficient which does not differ from zero at conventional significance levels.

However, one should not expect a strong level-of-pay and performance link, but rather a positive relationship between the change of pay and corporate performance. This is the relationship,

\footnotetext{
${ }^{9}$ Note, that since type of ownership is controlled for, the large negative effects do not reflect the fact that cooperatives are common in agriculture or that provision of health and education services is frequently carried out by state-owned companies.

${ }^{10}$ However, as emphasized by e.g. Prendergast (2002), this relationship is rarely found in empirical work on executive pay.
} 
which has been estimated numerous times especially on U.S. data, and on different samples, time periods and employing different specifications. This literature is well summarised by Murphy (1999). As was mentioned above, the elasticity of pay with respect to performance, which is typically referred to as the power of the incentives, may also be due to sorting. Recently, following Hall and Liebman (1998), this research makes use of information about the CEO's share and option holdings and finds a relatively strong link between executive compensation and company performance. In the Czech-Slovak data set this information is lacking. The omission of options holdings is, however, not a serious limitation as these are extremely rare. Share holdings information would have been a potentially more useful, however.

Table 3 contains estimates of log pay change equations for the pairs of years: 1998-99 and 19992000, where these log changes are regressed on the lagged profits over sales ratio controlling for individual traits, managerial position and firm size. The explanatory power of the equations is rather poor, but both firm size and more importantly, corporate performance turn out significant. The latter furthermore attaches a relatively large and positive coefficient. Thus, Czech managers seem to have reasonably strong incentives to increase the profitability of the companies they are heading. ${ }^{11}$ However, another notable feature of the results in Table 3 is that the fairly strong sizewage change relation. So, expanding firm size with unchanged profits also yields higher compensation, too.

\subsection{Managerial compensation}

Tables 4 and 5 give the corresponding estimation results from compensation equations for several groups of managerial employees. In the main, they have much in common with those reported above for samples including CEO's only ${ }^{12}$, and consequently, the following discussion will be restricted to those cases where they differ. Beginning with individual traits, it can be noted that for managerial employees, the pay-age link is now absent also in the SR, the gender pay differential is slightly smaller, and that in the CR the return to higher education is smaller than for

\footnotetext{
11 To what extent this is due to the managers holding shares in the companies they are employed at, would be a most interesting question to address. According to Claessens and Djankov's (1999) study, executives' stock ownership in publicly listed Czech companies does not improve enterprise performance. However, their study lacks information about managerial compensation.

${ }^{12}$ In general the magnitude of the impact of several of the explanatory variables are smaller than for CEO pay.
} 
CEO's. The firm size effect is, unlike for the CEO's, insignificant in CR, whereas in the Slovak estimations it is quite big (as it was for CEO's only, too).

Having access to larger samples of managerial employees, I am also able to examine the influence of the manager's job level on his compensation. In order to facilitate a comparison across firms, the classification of managers into job levels has to be rather crude. In the table, four groups are used; the omitted reference category is CEO's.

According to the estimates, there is a discernible pay-rank relationship in the Czech firms. Furthermore, the differences in compensation between the chief executive and the other managers are relatively large; at least compared to some European countries like Denmark (Eriksson 1998) but more in accordance with US evidence (Carpenter and Wade 2002). Thus, ceteris paribus, the Czech CEO's earn 60 to 80 per cent more than the other executives at the next levels of the hierarchy in the firm. The corresponding picture for the Slovak managers is much less clear; the CEO's are paid more, but compared to their Czech colleagues less relative to other executives (30 to 40 per cent). Recognising standard errors, there are actually only two levels. The differences in the pay-rank relations between the two countries suggest that in the Czech Republic the advances towards a more market-oriented, incentive-based reward system for managers have been greater than in Slovakia.

Compared to the analysis on the CEO samples, I find for CR smaller differences between firms with different types of ownership, but for SR differences are of about the same magnitude. Notably, managers in Czech state-owned firms now obtain the same pay as in private-owned firms. Interestingly the impact of ownership type is larger for the Slovak managers. The pattern of the industry and region effects for CEO's is largely replicated for the other managers.

\section{CEO turnover}

So far I have only discussed pay as the sole incentive for managerial employees. But there are other incentives that need to be taken into account. One, not touched on in this paper, is promotion prospects and wage gains associated therewith emphasised by tournament models 
(Lazear and Rosen 1981). Another to which I turn next is the threat of being turned over. An accumulating body of research has documented an inverse relationship between CEO removal and corporate performance. ${ }^{13}$ I have estimated probit models for CEO turnover in CR with corporate performance variables -- lagged as well as differenced -- as explanatory variables; see Table 6. Executives may of course also leave the firm because they want to retire as ordinary employees normally do. In order to rule out these cases, I have excluded from the sample all CEO's above the age of 60 . Another reason for executive mobility is that they move due to receiving a better job offers in another firm. Like previous studies, I have no information about that. $^{14}$

The dependent variable is equal to one if the CEO has been removed out off office since the previous year. The coefficient on lagged profits is negative and the same is true for the change in profits compared to last year. Thus, both a low level of profits and a decrease therein, increase the likelihood that the chief executive's employment relation is terminated. The changes-in-sales variable is insignificant, so growth without profits does not yield further years of service. The size of the firm has, however, a positively signed coefficient, indicating that CEO's in larger firms have a higher probability of surviving in their current jobs. One reason for this could be that larger firms have a more dispersed ownership and therefore, building a board majority to remove the CEO is more difficult or takes a longer time. Another explanation could be that bigger firms have more skilled executives and hence it is harder to find substitutes for them, especially in a managerial labour market characterised by shortage of managerial skills. Yet a third possibility, I found some support of in connection with the analysis of compensation, is that CEOs's in large firms have more power than others (Finkelstein and Hambrick 1996), and are consequently more difficult to turn over.

\footnotetext{
${ }^{13}$ Although most of the research is from the nineties, this literature is quite large. Some first model-setting papers are Coughlan and Schmidt (1985), Jensen and Murphy (1990) and Kaplan (1994). I am not aware any papers concerned with this relationship in a transition economy framework (save the study by Groves et al. (1995) on Chinese data). Claessens and Djankov (1999) look at the reverse relationship: the impact of change of management on corporate performance.

${ }_{14}$ The control for age has a negatively signed coefficient implying that younger executives have a higher turnover probability. This is consistent with other explanations such as entrenchment, but may also be due to voluntary job changes.
} 


\section{Concluding remarks}

Using data on managerial employees and their employers from both Czech and Slovak republics, I examine the determinants of executive compensation and CEO turnover in the countries at the end of the nineties in order to contribute to the very small literature on managerial labour markets in transition economies.

I find that private- and foreign (and private) owned companies are paying their CEO's as well as their other managerial employees higher compensation than firms operating without a profit motive. Similar to previous studies of Czech and Slovak non-managerial employees, I find that higher education pays off in terms of considerably higher pay also for managers. Likewise, there is a rather large gender pay gap in the higher echelons of firms.

Notably, a strong firm size effect can be observed in both levels and changes of executive pay. In the Czech Republic, company performance also influences growth in CEO compensation, implying that there are indeed incentives for top management to increase profitability. Due to lack of corporate performance information for Slovakia, a corresponding analysis cannot be carried out. There aere some indications, however, that incentives are considerably weaker in the Slovak Republic. On the other hand, during the years 1998-2000 there are traces of a tendency towards stronger incentives also for Slovak managers.

A potentially strong form of incentives for CEO's is the threat of being removed out of office. The estimates from CR provide some evidence that poor company performance results in a higher likelihood that the chief executive is turned over. 


\section{References}

Aghion, P., Blanchard, O. and Burgess, S. (1994), "The Behaviour of State Firms in Eastern Europe, Pre Privatization", European Economic Review, 38, pp.1327-1349

Barberis, N., Boycko, M., Shleifer, A. and Tsukanova, N. (1996), "How Does Privatization Work? Evidence from the Russian Shops", Journal of Political Economy, 104, pp. 764-790

Bebchuk, L., Fried, J. and Walker, D. (2002),"Managerial Power and Rent Extraction in the Design of Executive Compensation", The University of Chicago Law Review, 69, pp. 751-846

Bertrand, M. and Mullainathan, S. (2000), Do CEOs Set Their Own Pay? The Ones Without Principals Do. National Bureau of Economic Research Working Paper 7604

Carpenter, M. and Wade, J. (2002), "Micro-Level Opportunity Structures as Determinants of Non-CEO Pay", Academy of Management Journal, 45, pp. 1085-1103

Claessens, S. and Djankov, S. (1999), "Enterprise Performance and Management Turnover in the Czech Republic", European Economic Review, 43, pp. 1115-1124

Conyon, M. and Murphy, K. (2000), “The Prince and the Pauper? CEO Pay in the United States and United Kingdom”, Economic Journal, 110, pp. F640-F671

Coughlan, A. and Schmidt, R. (1985), "Executive Compensation, Management Turnover, and Firm Performance: An Empirical Investigation", Journal of Accounting and Economics, 7, pp. 43-66

Djankov, S. and Murrell, P. (2002), "Enterprise Restructuring in Transition: A Quantitative Survey", Journal of Economic Literature, 40, pp. 739-792

Eriksson, T. (1999), "Executive Compensation and Tournament Theory: Empirical Tests on Danish Data", Journal of Labor Economics, 17, pp. 224-242 
Eriksson, T. (2000), "What Determines Executive Pay? Evidence from Denmark", Long Range Planning, 33, pp. 544-559

Eriksson, T., Gottvald, J. and Mrázek, P. (1999), “An Analysis of the Determinants of Managerial Pay in the Czech Republic", Prague Economic Papers, 8, pp. 209-219

Estrin, S. (2002), "Competition and Corporate Governance in Transition", Journal of Economic Perspectives, 16, pp. 101-124

Finkelstein, S. and Hambrick, D. (1996), Strategic Leadership: Top Executives and their Organizations. Minneapolis: West Publishing Company

Frydman, R., Hessel, M. and Rapaczynski, A. (1999), "Why Ownership Matters? Human capital and Incentives in the Restructuring of Enterprises in Central Europe", in: Fox, M. and Heller, M. (eds.), Corporate Governance Lessons for Transition Economy Reforms. Princeton University Press

Groves, T., Hong, Y., McMillan, J. and Naughton, B. (1994), “Autonomy and Incentives in Chinese State Enterprises", Quarterly Journal of Economics, 109, pp. 183-209

Groves, T., Hong, Y., McMillan, J. and Naughton, B. (1995), “China's Evolving Managerial Labor Market”, Journal of Political Economy, 103, pp. 873-892

Hall, B. and Liebman, J. (1998), “Are CEOs Really Paid Like Bureaucrats?”, Quarterly Journal of Economics, 113, pp. 653-691

Jensen, M. and Murphy, K. (1990), "Performance Pay and Top Management Incentives”, Journal of Political Economy, 98, pp. 225-264

Jones, D. and Kato, T. (1996), "The Determinants of Chief Executive Compensation in Transitional Economies: Evidence from Bulgaria”, Labour Economics, 3, pp. 319-336 
Jones, D. and Kato, T. (1998), Chief Executive Compensation During Early Transition: Further Evidence from Bulgaria. The William Davidson Institute working paper 146, University of Michigan Business School

Jones, D., Kato, T. and Avramarov, S. (1995), "Managerial Labour Markets in Transitional Economies: Evidence from Bulgaria”, International Journal of Manpower, 16, pp. 14-24

Kaplan, S. (1994), “Top Executive Rewards and Firm Performance: A Comparison of Japan and the United States", Journal of Political Economy, 102, pp. 510-546

King, L. (2001), The Basic Features of Postcommunist Capitalism in Eastern Europe: Firms in Hungary, the Czech Republic, and Slovakia. Westport: Praeger

Lazear, E. (2000), "Performance Pay and Productivity", American Economic Review, 90, pp.1346-1361

Lazear, E. (2002), Personnel Economics: Incentives or Sorting? Keynote speech at the conference Incentives and Beyond - The Economics of Personnel and Organizations, CEPR/SITE Stockholm

Lazear, E. and Rosen, S. (1981), "Rank-Order Tournaments as Optimum Labor Contracts", Journal of Political Economy, 89, pp. 841-864

Murphy, K. (1999), "Executive Compensation", in: Ashenfelter, O. and Card. D., (eds.), Handbook of Labor Economics, vol. 3., pp. 2486-2563. Amsterdam: North-Holland

Prendergast, C. (2002), “The Tenuous Trade-off between Risk and Incentives”, Journal of Political Economy, 110, pp.1035-1070

Roland, G. and Sekkat, K. (2000), "Managerial Career Concerns, Privatization and Restructuring in Transition Economies", European Economic Review, 44, pp. 1857-1872

Rosen, S. (1992), "Contracts and the Market for Executives", in: Werin, L. and Wijkander, H. (eds.), Contract Economics, pp. 181-211. Oxford: Blackwell 
Shleifer, A. and Vishny, R. (1997), "A Survey of Corporate Governance”, Journal of Finance, 52, pp. $737-783$

Svejnar, J. (1999), "Labor Markets in the Transitional Central and East European Economies”, in: Ashenfelter, O. and Card, D., (eds.), Handbook of Labor Economics, vol. 3., pp. 2809-2857. Amsterdam: North-Holland 
Table 1.Czech and Slovak CEO's - some summary statistics

\begin{tabular}{|c|c|c|}
\hline & Czech CEO's 2000 & Slovak CEO's 2000 \\
\hline $\begin{array}{l}\text { Average compensation (in local } \\
\text { currency) }\end{array}$ & 873.339 & 558.772 \\
\hline (Coeff. of variation) & $(0.94)$ & $(1.05)$ \\
\hline \multicolumn{3}{|l|}{ Thereof $(\%)$ : } \\
\hline Base salary & 66.0 & 70.6 \\
\hline Bonuses & 2.7 & 4.9 \\
\hline Premium pay & 29.7 & 24.5 \\
\hline Other (incl. board comp.) & 1.6 & 0 \\
\hline \multicolumn{3}{|l|}{ Individual traits: } \\
\hline Age & 47.8 & 46.8 \\
\hline Proportion males & 92.9 & 83.4 \\
\hline Prop. university education & 67.3 & 66.6 \\
\hline \multicolumn{3}{|l|}{ Firm characteristics: } \\
\hline Number of employees & 582.6 & 336.9 \\
\hline (Coeff. of variation) & $(2.26)$ & $(4.78)$ \\
\hline Capital region $(\%)$ & 14.5 & 21.4 \\
\hline \multicolumn{3}{|l|}{ Ownership (\%): } \\
\hline Private owned & 49.8 & 52.1 \\
\hline State owned & 17.2 & 26.2 \\
\hline Foreign owned & 11.7 & 8.9 \\
\hline Cooperative & 8.2 & 8.1 \\
\hline Mixed & 13.1 & 4.7 \\
\hline \multicolumn{3}{|l|}{ Industry (\%): } \\
\hline Agriculture & 9.1 & 4.6 \\
\hline Manufacturing & 46.0 & 38.4 \\
\hline Energy & 5.8 & 1.5 \\
\hline Construction & 6.1 & 4.5 \\
\hline Services & 32.9 & 51.0 \\
\hline
\end{tabular}


Table 2a. Compensation equations for Czech CEO's 1998 - 2000*

\begin{tabular}{|c|c|c|c|}
\hline \multirow{3}{*}{$\overline{~ A g e}$} & 1998 & 1999 & 2000 \\
\hline & -0.023 & 0.040 & 0.026 \\
\hline & $(0.019)$ & $(0.032)$ & $(0.033)$ \\
\hline Age squared/100 & $\begin{array}{c}0.032 \\
(0.023)\end{array}$ & $\begin{array}{l}-0.029 \\
(0.034)\end{array}$ & $\begin{array}{l}-0.017 \\
(0.034)\end{array}$ \\
\hline Male & $\begin{array}{l}0.200^{*} \\
(0.112)\end{array}$ & $\begin{array}{c}0.351 * * * \\
(0.111)\end{array}$ & $\begin{array}{c}0.373 * * * \\
(0.101)\end{array}$ \\
\hline University degree & $\begin{array}{c}0.532 * * * \\
(0.054)\end{array}$ & $\begin{array}{c}0.437 * * * \\
(0.057)\end{array}$ & $\begin{array}{c}0.501 * * * \\
(0.057)\end{array}$ \\
\hline $\begin{array}{l}\text { Ln number of } \\
\text { employees }\end{array}$ & $\begin{array}{c}0.109^{* * *} \\
(0.018)\end{array}$ & $\begin{array}{c}0.092^{* * * *} \\
(0.018)\end{array}$ & $\begin{array}{c}0.158^{* * * *} \\
(0.024)\end{array}$ \\
\hline \multicolumn{4}{|l|}{ Firm type: } \\
\hline Private owned & reference & reference & reference \\
\hline Cooperative & $\begin{array}{c}-0.262 * * * \\
(0.099)\end{array}$ & $\begin{array}{c}-0.312^{* * * *} \\
(0.105)\end{array}$ & $\begin{array}{c}-0.307 * * * \\
(0.103)\end{array}$ \\
\hline State owned & $\begin{array}{l}-0.129 \\
(0.085)\end{array}$ & $\begin{array}{c}-0.161^{*} \\
(0.088)\end{array}$ & $\begin{array}{c}-0.259^{* * * *} \\
(0.093)\end{array}$ \\
\hline Foreign owned & $\begin{array}{c}0.246^{* * *} \\
(0.080)\end{array}$ & $\begin{array}{c}0.396 * * * \\
(0.084)\end{array}$ & $\begin{array}{c}0.455^{* * *} \\
(0.088)\end{array}$ \\
\hline Mixed ownership & $\begin{array}{c}0.249^{* * *} \\
(0.075)\end{array}$ & $\begin{array}{c}0.293 * * * \\
(0.077)\end{array}$ & $\begin{array}{c}0.314 * * * \\
(0.085)\end{array}$ \\
\hline $\begin{array}{l}\text { Profit-sales ratio in } \\
\text { previous year }\end{array}$ & n.a. & $\begin{array}{c}0.043 \\
(0.094)\end{array}$ & $\begin{array}{c}0.060 \\
(0.040)\end{array}$ \\
\hline $\begin{array}{l}\mathrm{N} \text { of obs } \\
\mathrm{R}^{2} \text { (adj) }\end{array}$ & $\begin{array}{c}600 \\
0.420 \\
\end{array}$ & $\begin{array}{c}600 \\
0.400 \\
\end{array}$ & $\begin{array}{c}600 \\
0.439 \\
\end{array}$ \\
\hline
\end{tabular}

* Numbers in parentheses: absolute standard errors. The 10, 5, ands 1 per cent significance levels are denoted by $* * *$, and ${ }^{* *}$, respectively. 
Table 2b. Compensation equations for Slovak CEO's, 1998-2000*

\begin{tabular}{lccc}
\hline & $\mathbf{1 9 9 8}$ & $\mathbf{1 9 9 9}$ & $\mathbf{2 0 0 0}$ \\
\hline Age & $0.073^{* * *}$ & $0.077^{* * *}$ & $0.110^{* * *}$ \\
Age squared/100 & $(0.023)$ & $(0.025)$ & $(0.029)$ \\
& $-0.068^{* * *}$ & $-0.073^{* * *}$ & $-0.094^{* * *}$ \\
Male & $(0.025)$ & $(0.027)$ & $(0.031)$ \\
& $0.181^{* * *}$ & $0.199 * * *$ & $(0.085)$ \\
University degree & $(0.065)$ & $(0.068)$ & $0.409^{* * *}$ \\
& $0.251^{* * *}$ & $0.202^{* * *}$ & $(0.067)$ \\
Ln number of & $(0.049)$ & $(0.056)$ & $0.445^{* * *}$ \\
employees & $0.334^{* * *}$ & $0.358^{* * *}$ & $(0.101)$ \\
& $(0.039)$ & $(0.043)$ & \\
Firm type: & & & reference \\
Private owned & & & -0.093 \\
Cooperative & reference & reference & $(0.123)$ \\
State owned & $-0.177^{* *}$ & $-0.142 *$ & $-0.207 * *$ \\
Foreign owned & $(0.076)$ & $(0.081)$ & $(0.101)$ \\
& $-0.236^{* * *}$ & $-0.210^{* * *}$ & $(0.116)$ \\
Mixed ownership & $(0.065)$ & $(0.078)$ & 0.149 \\
& $0.386^{* * *}$ & $0.401 * * *$ & $(0.150)$ \\
N of obs & $(0.100)$ & $(0.094)$ & 862 \\
$\mathrm{R}^{2}$ (adj.) & 0.036 & -0.074 & 0.209 \\
\hline
\end{tabular}

*. Dependent variable: log total compensation. Other independent variables included but not shown are seven regional dummies and thirteen industry dummies. 
Table 3. Earnings change estimations for Czech managerial employees 1999-2000*

\begin{tabular}{lcc}
\hline & CEO's & All managerial employees \\
\hline Age & 0.001 & -0.001 \\
& $(0.009)$ & $(0.008)$ \\
(Age squared)/100 & -0.002 & -0.001 \\
& $(0.011)$ & $(0.008)$ \\
Male & 0.008 & $0.034^{* *}$ \\
University education & $(0.020)$ & $(0.016)$ \\
& 0.006 & 0.006 \\
CEO & $(0.012)$ & $(0.013)$ \\
& & 0.018 \\
Assistant manager & & $(0.023)$ \\
& & $-0.117^{* *}$ \\
Organisational manager & & $(0.052)$ \\
& & -0.023 \\
Ln employees & & $(0.016)$ \\
& $0.017^{* *}$ & $0.021^{* * *}$ \\
Profits/sales in previous year & $(0.007)$ & $(0.006)$ \\
Industry dummies & $0.248^{* * *}$ & $0.257^{* *}$ \\
Regional dummies & $(0.066)$ & $(0.108)$ \\
Firm type dummies & yes & yes \\
& yes & yes \\
N of obs & yes & yes \\
$\mathrm{R}^{2}$ (adj.) & & \\
\hline
\end{tabular}

*. Dependent variable: log change in total compensation 1999-2000. Excluded from estimation samples: state-owned firms and cooperatives. 
Table 4. Compensation equation estimates for managerial employees, in CR and SR, 1998 and 2000

\begin{tabular}{|c|c|c|c|c|}
\hline & CR 1998 & CR 2000 & SR 1998 & SR 2000 \\
\hline \multirow[t]{2}{*}{ Age } & $0.055 * * *$ & $0.041 * * *$ & $0.088 * * *$ & 0.044 \\
\hline & $(0.009)$ & $(0.009)$ & $(0.031)$ & $(0.041)$ \\
\hline \multirow{2}{*}{ (Age sq.)/100 } & $-0.051 * * *$ & $-0.039 * * *$ & $-0.087 * * *$ & -0.033 \\
\hline & $(0.010)$ & $(0.010)$ & $(0.034)$ & $(0.043)$ \\
\hline \multirow[t]{2}{*}{ Male } & $0.231 * * *$ & $0.239 * * *$ & 0.137 & $0.194^{*}$ \\
\hline & $(0.020)$ & $(0.020)$ & $(0.084)$ & $(0.112)$ \\
\hline \multirow[t]{2}{*}{ University educ. } & $0.276 * * *$ & $0.268 * * *$ & $0.310 * * *$ & $0.426 * * *$ \\
\hline & $(0.034)$ & $(0.032)$ & $(0.064)$ & $(0.086)$ \\
\hline \multirow[t]{2}{*}{ Ln employees } & 0.038 & 0.024 & $0.032 * * *$ & $0.047 * * *$ \\
\hline & $(0.028)$ & $(0.032)$ & $(0.005)$ & $(0.017)$ \\
\hline \multirow[t]{2}{*}{ Managerial level 4} & $-0.830 * * *$ & $-0.840 * * *$ & -0.044 & -0.378 \\
\hline & $(0.094)$ & $(0.097)$ & $(0.331)$ & $(0.393)$ \\
\hline \multirow[t]{2}{*}{ Level 3} & $-0.585^{* * *}$ & $-0.652 * * *$ & -0.038 & $-0.289 * * *$ \\
\hline & $(0.051)$ & $(0.052)$ & $(0.072)$ & $(0.087)$ \\
\hline \multirow[t]{2}{*}{ Level 2} & $-0.636^{* * *}$ & $-0.715 * * *$ & -0.102 & $-0.349 * * *$ \\
\hline & $(0.058)$ & $(0.059)$ & $(0.063)$ & $(0.095)$ \\
\hline CEO & reference & reference & reference & reference \\
\hline \multicolumn{5}{|l|}{ Ownership: } \\
\hline \multirow[t]{2}{*}{ Cooperative } & $-0.148 * * *$ & $-0.151 * * *$ & -0.143 & $-0.303 * *$ \\
\hline & $(0.038)$ & $(0.039)$ & $(0.094)$ & $(0.137)$ \\
\hline \multirow[t]{2}{*}{ State-owned } & -0.046 & -0.035 & $-0.265 * * *$ & $-0.369 * * *$ \\
\hline & $(0.032)$ & $(0.033)$ & $(0.082)$ & $(0.112)$ \\
\hline \multirow[t]{2}{*}{ Foreign owned } & $0.204 * * *$ & $0.311 * * *$ & $0.405 * * *$ & $0.483 * * *$ \\
\hline & $(0.030)$ & $(0.031)$ & $(0.116)$ & $(0.154)$ \\
\hline \multirow[t]{2}{*}{ Mixed ownership } & $0.076 * * *$ & $0.112 * * *$ & 0.077 & -0.011 \\
\hline & $(0.025)$ & $(0.027)$ & $(0.161)$ & $(0.175)$ \\
\hline Purely private & reference & reference & reference & reference \\
\hline \multicolumn{5}{|l|}{ Industry: } \\
\hline \multirow[t]{2}{*}{ Agriculture } & $-0.252 * * *$ & $-0.235 * * *$ & -0.330 & $-0.720 *$ \\
\hline & $(0.084)$ & $(0.087)$ & $(0.289)$ & $(0.303)$ \\
\hline \multirow[t]{2}{*}{ Process ind. } & -0.057 & -0.013 & -0.095 & -0.304 \\
\hline & $(0.076)$ & $(0.080)$ & $(0.277)$ & $(0.259)$ \\
\hline \multirow[t]{2}{*}{ Machine } & -0.063 & -0.024 & 0.112 & -0.258 \\
\hline & $(0.078)$ & $(0.082)$ & $(0.291)$ & $(0.281)$ \\
\hline \multirow[t]{2}{*}{ Energy } & 0.087 & $0.160 *$ & -0.348 & -0.082 \\
\hline & $(0.081)$ & $(0.085)$ & $(0.347)$ & $(0.362)$ \\
\hline \multirow[t]{2}{*}{ Construction } & 0.070 & 0.081 & -0.150 & -0.460 \\
\hline & $(0.083)$ & $(0.087)$ & $(0.294)$ & $(0.316)$ \\
\hline \multirow[t]{2}{*}{ Repair } & $-.0 .147 *$ & -0.134 & -0.094 & -0.161 \\
\hline & $(0.086)$ & $(0.089)$ & $(0.286)$ & $(0.282)$ \\
\hline \multirow[t]{2}{*}{ Hotels, restaurants } & 0.296 & 0.183 & -0.242 & -0.258 \\
\hline & $(0.209)$ & $(0.202)$ & $(0.402)$ & $(0.312)$ \\
\hline
\end{tabular}




\begin{tabular}{|c|c|c|c|c|}
\hline Transports, tele & $\begin{array}{c}0.008 \\
(0.081)\end{array}$ & $\begin{array}{c}0.058 \\
(0.084)\end{array}$ & $\begin{array}{c}0.219 \\
(0.292)\end{array}$ & $\begin{array}{l}-0.299 \\
(0.295)\end{array}$ \\
\hline Banks, fin. Inst. & $\begin{array}{c}0.201 * * \\
(0.094)\end{array}$ & $\begin{array}{c}0.518 * * * \\
(0.098)\end{array}$ & $\begin{array}{l}-0.269 \\
(0.645)\end{array}$ & $\begin{array}{c}0.254 \\
(0.461)\end{array}$ \\
\hline $\mathrm{R} \& \mathrm{D}$ & $\begin{array}{c}0.062 \\
(0.091)\end{array}$ & $\begin{array}{c}0.184 * * \\
(0.093)\end{array}$ & $\begin{array}{l}-0.171 \\
(0.285)\end{array}$ & $\begin{array}{l}-0.361 \\
(0.270)\end{array}$ \\
\hline Education serv. & $\begin{array}{c}-0.769 * * * \\
(0.084)\end{array}$ & $\begin{array}{c}-0.653 * * * \\
(0.087)\end{array}$ & $\begin{array}{c}-0.507^{*} \\
(0.296)\end{array}$ & $\begin{array}{c}-0.642 * * \\
(0.289)\end{array}$ \\
\hline Health services & $\begin{array}{l}-0.093 \\
(0.088)\end{array}$ & $\begin{array}{l}-0.022 \\
(0.090)\end{array}$ & $\begin{array}{l}-0.311 \\
(0.293)\end{array}$ & $\begin{array}{c}-0.531 * * \\
(0.273)\end{array}$ \\
\hline Other services & $\begin{array}{c}0.088 \\
(0.096)\end{array}$ & $\begin{array}{c}0.153 \\
(0.099)\end{array}$ & $\begin{array}{c}-0.222 \\
(0.295)\end{array}$ & $\begin{array}{c}-0.533^{* *} \\
(0.277)\end{array}$ \\
\hline Mining & reference & reference & reference & reference \\
\hline Region*: & & & & \\
\hline Capital region & reference & reference & reference & reference \\
\hline 2 & $\begin{array}{c}0.038 \\
(0.036)\end{array}$ & $\begin{array}{c}0.052 \\
(0.036)\end{array}$ & $\begin{array}{c}-0.483 * * * \\
(0.112)\end{array}$ & $\begin{array}{l}-0.248 \\
(0.155)\end{array}$ \\
\hline 3 & $\begin{array}{c}0.101^{* * *} * \\
(0.033)\end{array}$ & $\begin{array}{c}0.119 * * * \\
(0.035)\end{array}$ & $\begin{array}{c}-0.506^{* * * *} \\
(0.104)\end{array}$ & $\begin{array}{c}-0.412 * * * \\
(0.144)\end{array}$ \\
\hline 4 & $\begin{array}{c}0.096^{* *} \\
(0.040)\end{array}$ & $\begin{array}{c}0.085^{* *} \\
(0.041)\end{array}$ & $\begin{array}{c}-0.291 * * * \\
(0.097)\end{array}$ & $\begin{array}{c}-0.250^{*} \\
(0.130)\end{array}$ \\
\hline 5 & $\begin{array}{c}-0.163 * * \\
(0.073)\end{array}$ & $\begin{array}{c}-0.189 * * * \\
(0.065)\end{array}$ & $\begin{array}{c}-0.338 * * * \\
(0.107)\end{array}$ & $\begin{array}{l}-0.206 \\
(0.134)\end{array}$ \\
\hline 6 & $\begin{array}{c}-0.006 \\
(0.031)\end{array}$ & $\begin{array}{c}-0.013 \\
(0.032)\end{array}$ & $\begin{array}{c}-0.228^{* *} \\
(0.097)\end{array}$ & $\begin{array}{c}-0.312^{* *} \\
(0.136)\end{array}$ \\
\hline 7 & $\begin{array}{c}0.028 \\
(0.042)\end{array}$ & $\begin{array}{c}0.061 \\
(0.047)\end{array}$ & $\begin{array}{c}-0.535^{* * * *} \\
(0.103)\end{array}$ & $\begin{array}{l}-0.254^{*} \\
(0.132)\end{array}$ \\
\hline 8 & $\begin{array}{c}-0.039 \\
(0.036)\end{array}$ & $\begin{array}{l}0.066^{*} \\
(0.037)\end{array}$ & & \\
\hline $\mathrm{R}^{2}$ (adj.) & 0.332 & 0.307 & 0.356 & 0.225 \\
\hline $\mathrm{N}$ of obs & 3,422 & 3,422 & 1,499 & 1,529 \\
\hline
\end{tabular}

* The regions for Czech Republic are: Prgaue, Central Bohemia, Budejovice, Plzen, Karlovy Vary, Usti n. Labem, Liberec, Hradec Kralove, Pardubice, Jihlava, Brno, Olomouc, Zlin and Ostrava. The regions for Slovak Republic are: Bratislava, Trnava, Trencin, Nitra, Zilina, Banska Bystrica, Presov and Kosice. 
Table 5. Probit estimates of CEO turnover in Czech Republic, 1998-99 and 1999-2000*

\begin{tabular}{lcc}
\hline & $\mathbf{1 9 9 8 - 9 9}$ & $\mathbf{1 9 9 9 - 2 0 0 0}$ \\
\hline The firm: & $0.262^{* * *}$ & $0.163^{* *}$ \\
Ln number of employees in & $(0.093)$ & $(0.081)$ \\
previous year & $-0.011^{* *}$ & $-0.013^{* *}$ \\
Gross profits in previous year & $(0.006)$ & $(0.006)$ \\
& $-0.290^{* *}$ & -0.076 \\
Change in profits & $(0.012)$ & $(0.056)$ \\
& 0.032 & 0.014 \\
Change in sales & $(0.024)$ & $(0.012)$ \\
& 0.060 & 0.086 \\
Private owned & $(0.191)$ & $(0.072)$ \\
& 0.392 & 0.244 \\
State-owned & $(0.355)$ & $(0.298)$ \\
& -0.134 & -0.163 \\
Foreign owned & $(0.294)$ & $(0.179)$ \\
& & \\
The CEO: & $-0.621^{* * *}$ & $-0.688^{* * *}$ \\
Aged 50 to 60 & $(0.181)$ & $(0.191)$ \\
University education & $-0.416^{* *}$ & $-0.598^{* *}$ \\
& $(0.178)$ & $(0.182)$ \\
N of obs & 337 & 273 \\
$\mathrm{R}^{2}$ (adj.) & 0.088 & 0.079 \\
\hline
\end{tabular}

*. Note: firms with a CEO above the age of 60 are excluded. 